\title{
Analisis Kesulitan Belajar Matematika Siswa Kelas V pada Materi KPK dan FPB Madrasah Ibtidaiyah Negeri 2 Kota Palembang
}

\author{
TIARA ARISKA \\ Program Studi Pendidikan Guru Madrasah Ibtidaiyah, Universitas Islam Negeri Raden \\ Fatah Palembang \\ e-mail:ukhtitiara23@gmail.com
}

\begin{abstract}
ABSTRAK. This research aims to desrible the location of the difficulty students in learning mathematics in the material KPK and FPB. The studiwas conducted at MIN 2 Palembang subject main this research is a fifth grade student which numbered 40 people student. Type of apporoach in research this is qualitative and duantitative approache, data collection methods used is written test method observation and interview. Fromthe final result data obtained $40 \%$ students who have difficulty $45 \%$ understand the material and $15 \%$ moderate students. Internal factors and external factors, internal factors are the lack of attetntion when yhe teacher explains the material of KPK and FPB the difficulty of doing quentions in the form of stories one the KPK material and the lack interest in learning they undertand mathematics. Ekternal factors stem from their lack of understanding of the method used.
\end{abstract}

Kata kunci: Difficulties Study, Mathematics, KPK dan FPB

\section{PENDAHULUAN}

Pendidikan merupakan hal yang sangat penting dalam kehidupan manusia.tanpa pendidikan manusia tidak bisa memperoleh masa depan yang lebih baik karena Pendidikanlah manusia bisa mencapai apa yang di impikannya contohnya saja jika ingin menjadi seorang dokter atau politikus maka pendidikanlah yang berperan penting jika bukan karena pendidikan akan sulit sekali untuk menjadi seorang dokter maupun politikus mengapa demikian, karena didalam pendidikan terdapat banyak ilmu dan wawasan yang akan membimbing dan melatih kita untuk menjadi apa yang kita impikan.

Di dalam Undang-undang RI Nomor 20 tahun 2003 tentang sistem Pendidikan Nasional pada Bab 1 pasal 1 dikemukakan, bahwa pendidikan adalah usaha sadar dan terencana untuk mewujudkan suasana belajar dan proses pembelajaran agar peserta didik secara aktif mengembangkan potensi dirinya untuk memiliki kekuatan spritual keagamaan, pengendalian diri, kepribadian, kecerdasan, akhlak mulia serta keterampilan yag diperlukan dirinya, masyarakat, bangsa, dan negara (Amos Neolaka,2017,14).

Sedangkan menurut Ki Hajar Dewantara (Bapak Pendidikan Nasional Indonesia) menjelaskan bahwa pendidikan itu adalah sebuah tuntutan di dalam hidup tumbuhnya 
anak-anak,adapun maksudnya, pendidikan yaitu menuntun segala kekuatan kodrat yang ada pada anak-anak itu,agar mereka sebagai manusia dan sebagai anggota masyarakat dapatlah mencapai keselamatan dan kebahagiaan setinggi-tingginya (Stefanus M. Marbun,2018,10). Jadi dapat disimpulkan bahwa pendidikan itu ialah suatu kegiatan bimbingan pengajaran dan pelatihan, yang dilakukan secara sadar oleh seorang pendidik kepada terdidik untuk membentuk kepribadian dan kemampuan yang dimilikinya sehingga mereka dapat menjadi seorang insan yang berguna bagi kehidupan.

Pendidikan matematika dapat dikatakan salah satu pendidikan yang berpengaruh besar bagi kehidupan sehari-hari walaupun kebanyakan siswa tidak terlalu menyukai pelajaran ini karena terkesan lebih sulit dibanding pelajaran yang lainnya, mereka yang tidak menyukai pelajaran ini akan berusaha menghindar untuk tidak mepelajarinya lagi padahal matematika tidak akan pernah lepas dari kehidupan sehari hari karena setiap kegiatan yang kita lakukan akan selalu terhubung dengan matematika contoh kecilnya saja saat kita pergi ke pasar untuk berbelanja maka akan terjadi transaksi jual beli dan itu menggunakan perhitungan dalam prosesnya hingga mendapat sebuah kesepakatan antara kedua pihak. Melalui pendidikan matematika siswa diharapkan dapat menjadi manusia yang dapat berfikir secara kritis,logis, kratif, dan inovatif. Cornelius(dalam Abdulrrahman,2012) mengemukakan lima alasan perlunya siswa belajar matematika karena matematika merupakan 1). Sarana berpikir yang jelas dan logis, 2). Sarana untuk memecahkan masalah kehidupan sehari-hari, 3). Sarana mengenal pola-pola hubungan dan generalisasi pengalaman, 4). Sarana untuk mengembangkan kreativitas, dan 5). Sarana untuk meningkatkan kesadaran terhadap perkembangan budaya. Matematika adalah disiplin ilmu yang mempelajari tentang cara berpikir dan mengelola logika baik secara kuantitatif maupun secara kualitatif.

Indikator ketercapaian siswa dalam belajar matematika dapat dilihat dari kecakapan mengerjakan tugas-tugas yang diberikan seperti memahami soal cerita dan dapat membuat kalimat matematika dari soal cerita kemudian siswa dapat menyelesaikan soal soal yang diberikan, lalu menanamkan prinsip bahwa matematika bagian penting dalam kehidupan sehari-hari namun pada kenyataa nya saat ini para siswa belum sepenuhnya mencapai keberhasilan tersebut dilihat dari mereka mengerjakan soal ulangan maupun soal yang diberikan di papan tulis mereka masih sering keliru dalam mengisi jawaban dan juga belum sepenuhnya menganggap matematika bagian terpenting dalam kehidupan, para siswa berfikir belajar matematika adalah hal yang membosankan dan menakutkan dan itu sudah tertanam pada diri mereka sehingga saat materi berlangsung mereka tidak dapat memahaminya siswa yang memiliki kesulitan dalam memahami pelajaran matematika maka hasil belajarnya pun akan rendah. Sedangkan dalam pembelajaran di Sekolah dasar sendiri guru tidak bisa selalu memberikan perhatian khusus kepada siswa yang mengalai kesulitan belajar dikarenakan jumlah siswa cukup banyak dalam satu kelas dan waktu belajar di kelas yang terbatas.

Berdasarkan hasil yang dilakukan di kelas V MIN 2 Palembang sebagai salah satu MI yang menerapkan Kurikulum K13 ditemukan masih banyak siswa yang mengalami kesulitan dalam belajar matematika data yang ada menunjukan bahwa hasil belajar siswa terutama pada materi KPK dan FPB karena pada kurikulum K13 materi tersebut tidak diajarkan di kelas $\mathrm{V}$ namun diajarkan di kelas IV dan penerapannya dilakukan di kelas $\mathrm{V}$ karena mereka tidak memahami materi KPK dan FPB ketika di kelas IV Itulah mengapa 
saat di kelas $\mathrm{V}$ mereka mengalami kesulitan saat menyederhana FPB dan Menyamakan penyebut menggunakan KPK.

\section{METODOLOGI}

Metode penelitian merupakan cara yang digunakan peneliti untuk dapat mengumpulkan data-data yang ingin di teliti secara objektif dan akurat. Dalam penelitian ini peneliti menggunakan jenis penelitian kualitatif untuk menganalisis kesulitan belajar siswa pada materi KPK dan FPB, Menurut Nasution mengemukakan bahwa penelitian kualitatif pada hakikatnya adalah mengamati orang dalam lingkungannya, berintersksi dengan mereka berusaha memahami bahas dan tafsiran mereka tentang dunia sekitarnya. (Ajat Ru Kajat, 2018:1).

Adapun ciri-ciri penelitian kualitatif menurut Rukin (2019: 13) sebagaiberikut: (1) Sistematis, artinya bahasan tersusun secara teratur,berurutan menurut sistem, (2) Logis,artinya sesuai dengan logika,masuk akal,benar menurut penararan, (3) Empiris, artinya diperoleh dari pengaraman,penemuan,pengamatan dari lapangan penelitian, (4) Metodis, artinya yang kebenarannya diakui oleh penararan, (5) Umum, artinya menggenerasasi,meliputi keseluruhan dan tidakmenyangkut yang khusus saja, (6) Akumulatif, artinya bertambah terus makin berkembang dinamis.

Penelitian dilaksanakan pada tanggal 27 September 2019 di MIN 2 Kota Palembang. Subyek penelitian adalah siswa kelas $V$ yang berjumlah 40 orang siswa, langkah pertama dalam tahapan penelitian ini yaitu meminta izin kepada kepala sekolah MIN 2 Palembang yang kedua mengobservasi ke dalam kelas lalu memberikan tes tertulis kepada mereka mengenai materi KPK dan FPB mengkaji kesulitan-kesulitan siswa pada materi tersebut lalu tahapan yang ketiga wawancara kepada walikelas dan guru matematika kelas $\mathrm{V}$ mengenai apa penyebab dan cara mengatasi kesulitan yang di hadapi siswa dalam materi KPK dan FPB setelah itu mengumpulkan data data dari hasil pengamatan jadi metode pengumpulan data yang diperlukan dalam penelitian ini adalah Observasi, tes tertulis, dan wawancara

\section{HASIL DAN PEMBAHASAN}

Berdasarkan hasil penelitian yang dilakukan pada siswa kelas V di MIN 2 Kota Palembang tenyata masih terdapat kesulitan-kesulitan dalam memperlajari materi matematika khususnya materi KPK dan FPB. Kesulitan-kesulitan belajar seperti ini dapat terjadi apabila alokasi waktu yang kurang bagi siswa untuk memepelajari materi yang diberikan menurut (Sugihartono, 2007,152) berpendapat bahwa setiap siswa akan dapat menyelesaikan tugas belajarnya apabila diberi waktu yang cukup untuk belajar karena setiap materi yang diajarkan memiliki tingkat kesulitan yang berbeda tentunya setiap materi membuntuhkan waktu yang yang berbeda untuk menguasainya.itulah mengapa perlu untuk mengulang materi yang dipelajari karena dengan mengulang mempelajarinya kita dapat mengingatnya terus menerus. Data yang didapatkan menunjukan ada 15 siswa yang tidak mengerti materi KPK dan FPB mereka belum menguasai sebagian besar bahan pelajaran yang telah diajarkan. 


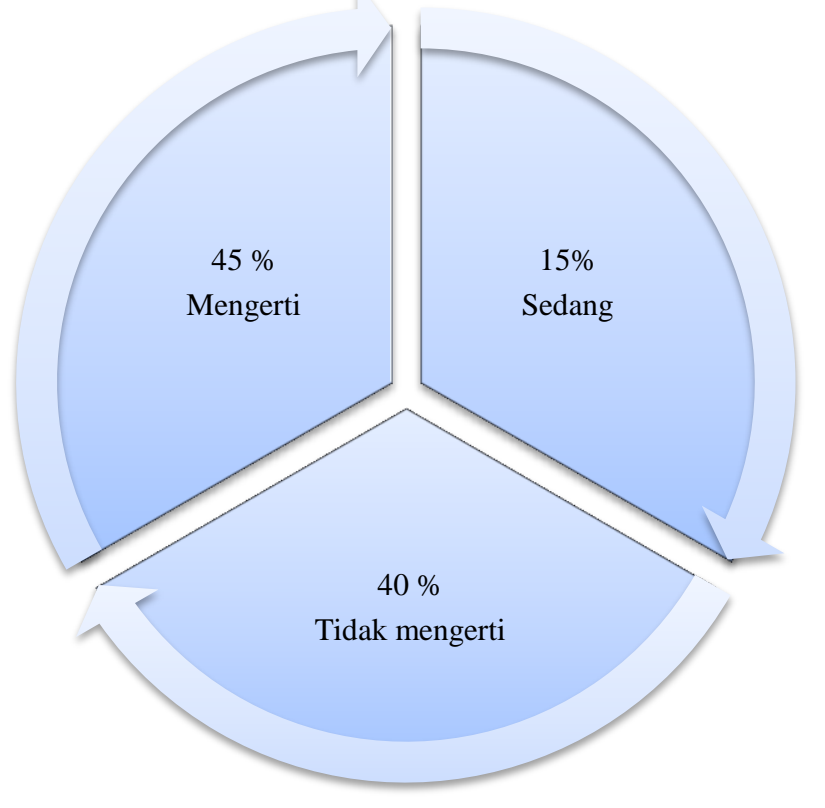

Gambar 1.

\section{Diagram Lingkaran Kemampuan Siswa Memahami Materi}

Menurut Djamarah, kesulitan belajar merupakan suatu keadaan di mana siswa dalam proses pembelajaran. Kesulitan belajar merupakan suatu keadaan di mana siswa tidak dapat belajar sebagaimana mestinya yang disebabkan oleh hambatan atau gangguan tertentu dalam proses pembelajaran sehingga siswa tidak dapat mencapai hasil belajar yang diharapkan(Husamah,2018,236). Dari hasil wawancara bersama guru matematika kelas V menunjukan bahwa kesulitan belajar materi KPK dan FPB di sebabkan oleh ketidakpahaman mereka pada saat di kelas IV padahal materi tersebut diajarkan pada kelas IV namun di digunakan di kelas $\mathrm{V}$ para siswa mengalami kesulitan dalam memahami soal berbentuk cerita dalam materi KPK dan FPB siswa kurang mampu mengubah permasalalahan yang berbentuk cerita ke dalam permasalahan matematis..

Itulah mengapa banyak siswa yang mengalami kesulitan selain itu juga kesulitan belajar siswa disebabkan oleh faktor intern faktor ekstern, salah satu faktor internal yaitu minat dan motivasi siswa dalam belajar matematika yang rendah menyebabkan kesulitan belajar minat dan motivasi belajar yang rendah dapat dilihat dari kurangnya perhatian siswa pada saat mengikuti pembelajaran matematika, malas bertanya pada saat pelajaran dan ribut di kelas pada saat pelajaran berlangsung. Sedangkan faktor eksternal yang menyebabkan kesulitan belajar berdasarkan wawancara ialah lingkungan sosial, lingkungan sosialterlihat dari siswa yang mengalami kesulitan dalam belajar kebanyakan dari latar belakang sosial yang kurang baik, seperti latar belaknag orang tua yang tingkat ekonominya rendah, orang tuanya yang bercerai ataupun yang kurang perhatian dari orang tuanya.

Menurut Fletcher, Aunurrahmann dalam Husamah(2018,252) Kesulitan belajar pada siswa dapat disebabkan oleh beberapa faktor : Pertama, Faktor Internal (a) Kurangnya minat dalam belajar Matematika (b) Kurangnya perhatian siswa dalam belajar matematika (c) Kurangnya motivasi siswa dalam belajar matematika (d) Kebiasaan tidak konsetrasi dalam belajar. Kedua, Faktor Eksternal (a) Lingkungan sekolah yang tidak nyaman (b) Fasilitas sekolah yang kurang memadai (c) Metode yang diajarkan guru sulit dimengerti siswa (d) Media pembelajaran yang kurang (e) Sumber belajar. 
Kesalahan yang dilakukan siswa dalam materi KPK dan FPB adalah kurangnya keterampilan mereka dalam menghitung dan mengahafal perkalian dan pembagian serta tidak memahami konsep materi KPK dan FPB, kesulitan keterampilan ini dapat terjadi karena beberapa kemungkinan, antara lain siswa tidak fokus saat guru menjelaskan, siswa ribut dan mengantuk saat guru menjelaskan Dalam hal ini guru hendaknya dapat memberikan penanganan yang tepat untuk meningkatkan hasil belajar siswa sesuai dengan letak kesulitan belajarnya. Untuk materi KPK dan FPB guru harus menyampaikan secara jelas bagaimana sistematika menghitung yang benar terus menerus memperhatikan hafalan perkalian mereka setiap pertemuannya. Ada beberapa cara untuk mengatasi para siswa yang mengalami kesulitan, yaitu: (1) Guru harus mengubah strategi pembelajaran dengan mempertimbangkan kemapuan siswa. (2) Melakukan pendekatan secara emosional dengan mengajari mereka yang mengalami kesulitan secara individu. (3) Memberikan motivasi motivasi yang akan membangkitkan minat belajar mereka sepuluh menit terakhir pelajaran, membuat. (4) Memanfaatkan ICT sebagai media yang lebih kreatif untuk mebangkitkan semangat siswa dalam belajar matematika dengan cara menayangkan materi dengan videovideo/slide-slide, membuat game yang didalamnya berisikan soal soal matematika. (5) Menghilangkan kesan bahwa guru matematika adalah guru yang kejam dan menakutkan.

Dalam hal ini bukan hanya peran guru yang dibutuhkan namun peran orang tua dalam proses belajar siswa sangat dibutuhkan karena perhatian dan bimbingan orang tua motivasi dan dorongan untuk giat dalam belajar masih sangat penting untuk perkembangan belajar mereka. Orang tua harus lebih memperhatikan anaknya contoh: (1) Selepas pulang sekolah menanyakan kepada mereka mengenai pembelajaran yang dipelajari di sekolah. (2) Mengajari mereka supaya mengulang-ulang materi yang telah di pelajari di malam hari. (3) Mengawasai mereka untuk tidak bermain gadget terlalu sering. (4) Membiasakan mereka untuk membaca buku dan belajar, berkerjasama bersama walikelasnya dalam perkembangan belajar mereka di dalam kelas. (5) Memasukan mereka ke les tambahan. (6) Mengajak mereka untuk bermain bersama menikmati waktu liburan.

Karena dari hal kecil perilaku itulah dapat membuat mereka termotivasi untuk belajar dan menjadi anak yang cerdas anak yang memiliki minat belajar yang tinggi. Siswa MI masih membutuhkan kasih sayang yang lebih dari orang terdekat mereka cendrung memiliki emosi yang belum kuat seperti halnya orang dewasa. Itulah mengapa peran orang tua dan guru harus lebih di perhatikan lagi saat mengajari mereka karena saat mereka masih anak-anak inilah yang mampu untuk membentuk karakter serta kecerdasaan mereka sebagus dan sebaik mungkin karena ketika dewasa mereka sudah tidak dapat di bentuk lagi. 


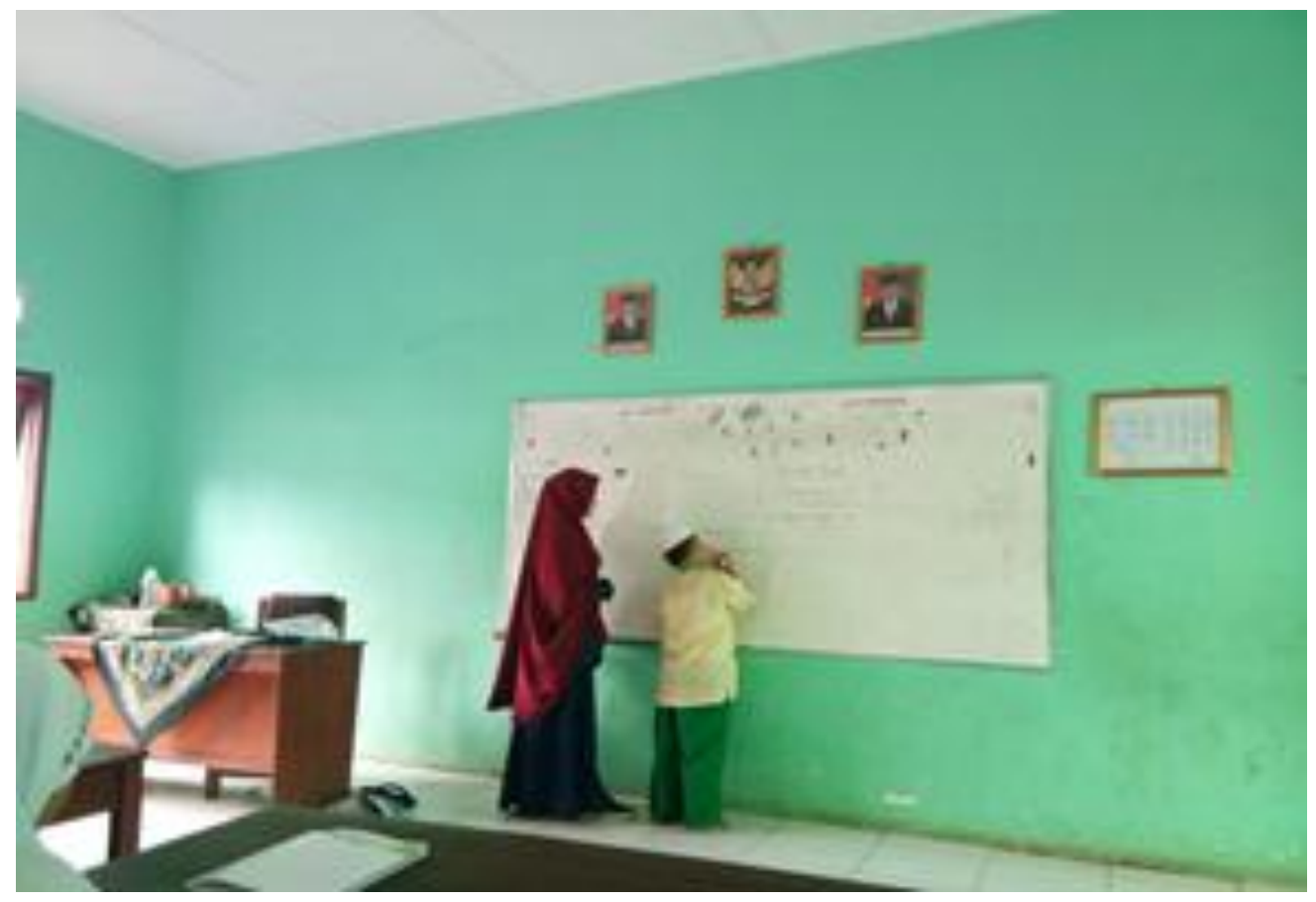

Gambar 2. Tes Tertulis

\section{KESIMPULAN}

Berdasarkan hasil penelitian dan analisis data yang telah dilakukan, maka dapat dapat ditarik kesimpulan bahwa bentuk bentuk kesulitan belajar siswa pada materi KPK dan FPB di MIN 2 Palembang Relatif sedang karena dari 40 siswa ada 15 siswa yang di kategorikan belum baik dalam materi KPK dan FPB hal ini terjadi karena materi KPK dan FPB dipelajari saat kelas IV sedangkan di kelas V materi KPK dan FPB di gunakan kembali mereka yang mengalami kesulitan adalah siswa yang pada saat kelas IV tidak terlalu memperhatikan saat guru menjelaskan, tidak mengulang-ulang kembali materi yang telah dipelajari serta tidak teralu hafalnya mereka dengan perkalian selain itu juga faktor internal dan faktor eksternal menjadi hal utama yang mempengaruhi kesulitan siswa dalam belajar materi matematika antara lain kurangnya minat mereka dalam mempelajari pelajaran matematika, kebiasaan tidak kosentrasi pada saat guru menjelaskan materi serta metode yang digunakan guru sulit untuk di mengerti sehingga mereka merasa bosan dalam pembelajaran berlangsung.

Solusi untuk mengatasi kesulitan belajar siswa dalam pelajaran matematika yaitu perhatian lebih dari guru dan orang tua, dari guru bisa dengan melakukan pendekatan secara emosional untuk mengetahui letak kesulitan mereka sehingga dapat di benahi, mengubah strategi pebelajaran menggunakan cara-cari yang lebih kreatif menggunakan teknologi seperti video-video, slide slide yang berisikan materi matematika lalu bisa membuat game yang di dalamnya terdapat materi matematika, dan memberikan motivasimotivasi untuk membangkitkan semangat belajar mereka. Sendangkan dari orang tua adalah setiap mereka pulang sekolah ditanyakan materi apa yang pelajari, mengajari mereka untuk terus mengulang-ulang materi yang telah dibahas, memberikan kasih sayang yang cukup. 


\section{REFERENSI} Cipta

Abdurahman. (2012). Pendidikan Bagi Anak yang Kesulitan Belajar. Jakarta: Rineka

Amos, N. (2017). Landasan Pendidikan. Depok: PT Kharisma Putra.

Arikunto, S. (2009). Dasar-Dasar Evaluasi Pendidikan. Jakarta: Bina Aksara.

Aziz, S. (2001). Kelambanan Dalam Belajar Penyebab dan Cara Penanganannya. Jakarta: Gema Insani.

Daryanto. (2010). Belajar dan Mengajar. Bandung: Yrama Widya, Bandung.

Dimyati \& Mudjiono. (2006). Belajar dan Pembelajaran. Jakarta: Rineka Cipta.

Djamarah. (2011). Psikologi Belajar, Penerbit Rineka Cipta, Jakarta.

Husamah, Dkk. (2018). Belajar dan Pembelajaran. Malang: Malang: Universitas Muhammadiyah Malang

Kajat, R, A. (2018). Pendekatan Penelitian Kualitatif. Yogyakarta: CV Buku Utama.

M. Marbun, S. (2018). Psikologi Pendidikan. Siduarjo: Uwais Inspirasi Indonesia.

Muhibbin, S. (2010). Psikologi Pendidikan. Bandung: PT. Remaja Rosdakarya.

Mulyadi. (2010). Diagnosis Kesulitan Belajar Dan Bimbingan Terhadap Kesulitan Belajar Khusus. Yogyakarta: Nuha Litera.

Mulyono, A. (2010). Pendidikan Bagi Anak Berkesulitan Belajar. Jakarta: Rineka Cipta.

Rukin. (2019). Pendekatan Kualitatif. Sulawesi: Yayasan Ahma Cendikia Indonesia.

Sugihartono. (2007). Psikologi Pendidikan. Yogyakarta: UNY Press. 